\title{
Kandungan Senyawa Fenolik Dan Terpenoid Ekstrak Etilasetat Daun Drimys piperita
}

\section{Phenolic and Terpenoid Compounds Content of Ethylacetate extracts of Drimys piperita Leaves}

\author{
Gino Nemesio Cepeda*, Meike Meilan Lisangan, Isak Silamba \\ Jurusan Teknologi Hasil Pertanian, Universitas Papua \\ "Email: ginocepeda.gc@gmail.com
}

\begin{abstract}
The medicinal plant of Drimys piperita known as "akway" is an aromatic plant growing in the area of the Arfak Mountains of West Papua. The plant has reddy brown barks with spicy flavor also evergreen thick leaves. The People who live around Arfak Mountains used it to treat malaria. The study was focused to know the content of phenolic and terpenoid compounds extracted from akway leaves using ethyl acetate solvent. Extraction of phytochemical compounds was done by using a method of maceration for 3 days. Extracts were fractionated by using $\mathrm{KOH}$ and $\mathrm{HCl}$ in a concentration of 5\%. Determination of total phenolic and flavonoid contents indicated that ethyl acetate extracts contained total phenol and flavonoid about 33,25 $\mathrm{mg} E A G / g$ dan 3,05 $\mathrm{mg} \mathrm{EQ/g}$ of extract respectively. The major compounds of terpenoid fraction were caryophyllene 14.43\%, isopatchoulane 11,60\%, 7methanoasulen 6,21\%, humulene 4,76\%, Octadecane 4.24\%, t-phytol 3.46\%, linalool 3,20\% and 1,8cyclotetradecadiyne 3,16\%. Ethylacetate extracts of akway leaves had potency as a source of cardiovascular disease prevention, anti-cancer, anti-diabetic, anti-microbial, anti-viral, antioxidant, anti-inflammatory, and anti-carcinogenic agents.
\end{abstract}

Keywords: Ethylacetate extract, phenolic, terpenoid, Drimys piperita

\begin{abstract}
Abstrak
Tumbuhan obat Drimys piperita dikenal dengan nama lokal "akway" adalah tumbuhan aromatik yang tumbuh di wilayah Pegunungan Arfak Papua Barat. Tumbuhan ini memiliki batang yang berwarna coklat kemerahan, rasa pedas juga memiliki daun yang tebal dan berwarna hijau. Masyarakat lokal yang bermukim di Pegunungan Arfak memanfaatkan akway sebagai tumbuhan untuk pengobatan malaria. Tujuan penelitian ini adalah untuk mengetahui kandungan senyawa fenolik dan terpenoid ekstrak etilasetat daun akway. Ekstraksi komponen fitokimia daun akway dengan pelarut etilasetat dilakukan menggunakan metode perendaman dengan waktu 3 hari. Fraksinasi senyawa terpenoid ekstrak etilasetat dilakukan menggunakan larutan $\mathrm{KOH} \mathrm{5 \%} \mathrm{dan} \mathrm{HCl} 5 \%$. Hasil penentuan kandungan total fenol dan flavonoid menunjukkan ekstrak etilasetat akway mengandung total fenol dan flavonoid masing-masing 33,25 mg EAG/g dan 3,05 mg EQ/g ekstrak. Senyawa penyusun utama fraksi terpenoid ekstrak etilasetat daun akaway adalah caryophyllene $14.43 \%$, isopatchoulane $11,60 \%$, 7methanoasulen 6,21\%, humulene 4,76\%, Octadecane 4.24\%, t-phytol 3.46\%, linalool 3,20\% dan 1,8cyclotetradecadiyne $3,16 \%$. Ekstrak etilasetat daun akway berpotensi sebagai sumber senyawa pencegah penyakit jantung, antikanker, aktivitas antidiabetes, antimikroba, antiviral, antioksidan, antiinflamasi dan antikarsinogenik.
\end{abstract}

Kata kunci: Ekstrak etilasetat, fenolik, terpenoid, Drimys piperita

\section{PENDAHULUAN}

Metabolit sekunder merupakan senyawasenyawa yang diproduksi oleh tumbuhan tetapi tidak diperlukan oleh tumbuhan untuk kehidupan sel dalam pertumbuhan dan perkembangan normal (Pagare dkk., 2015). Metabolit sekunder memiliki peranan sebagai pertahanan sel terhadap berbagai tekanan dan bahaya dari lingkungan tumbuhnya (Kabera dkk., 2014). 
Tumbuhan aromatik telah lama dikenal memiliki kemampuan membentuk senyawasenyawa metabolit sekunder yang dalam kehidupan manusia digunakan sebagai pengawet dan flavor pangan, aroma terapi dan obat tradisional. Senyawa metabolit sekunder yang diproduksi oleh tumbuhan dikelompokkan menjadi tiga kelompok utama, yaitu fenolik, terpenoid dan alkaloid (Kabera dkk., 2014). Masing-masing kelompok senyawa tersebut memiliki pengaruh farmakologis tertentu.

Drimys piperita yang dikenal oleh masyarakat lokal dengan sebutan "Akway" adalah tumbuhan aromatik yang dapat ditemukan di Pegunungan Arfak Papua Barat. Tumbuhan ini memiliki karakteristik warna kulit batang coklat kemerahan dengan rasa pedas serta memiliki daun tebal berwarna hijau. Masyarakat lokal yang bermukim di Pegunungan Arfak memanfaatkan akway sebagai tumbuhan untuk pengobatan malaria (Cepeda dkk., 2011a). Sebagai tumbuhan obat yang bersifat aromatik, akway mengandung minyak volatil pada bagian batang dan daunnya. Kulit batangnya menganduk minyak volatil dengan konsentrasi $0,37 \%$ dan minyak volatil yang terkandung dalam daun adalah 0,20\% (Cepeda dkk., 2011a; Cepeda dkk., 2011b).

Ekstrak akway dilaporkan mengandung berbagai senyawa metabolit sekunder yang memiliki efek farmakologis tertentu. Ekstrak metanol daun akway mengandung senyawa fenol $186.40 \mathrm{mg}$ EAG/g dan flavonoid $70 \mathrm{mg}$ $\mathrm{EQ} / \mathrm{g}$ dan sesquiterpen caryophyllene $0,37 \%$ (Cepeda dkk., 2010). Ekstrak metanol daun akway telah dibuktikan memiliki aktivitas antibakteri (Cepeda dkk., 2020). Sedangkan senyawa fenol dan flavonoid yang terkandung dalam ekstrak kulit batangnya masing-masing adalah 182,22 mg EAG/g dan 103,23 mg EQ/g untuk ekstrak metanol, 148,80 mg EAG/g dan $82,14 \mathrm{EQ} / \mathrm{g}$ untuk ekstrak etanol, 22,21 mg $\mathrm{EAG} / \mathrm{g}$ dan 2,30 $\mathrm{mg} \mathrm{EQ} / \mathrm{g}$. Ekstrak ini dilaporkan bersifat menangkal radikal bebas (Cepeda dkk., 2018).

Berdasarkan penelitian senyawa metabolit penyusun ekstrak akway tersebut, sampai saat ini belum pernah dilaporkan senyawa metabolit penyusun ekstrak etilasetat daun akway. Oleh karena itu, penelitian ini memiliki tujuan untuk mengetahui senyawa metabolit sekunder kelompok fenolik yang meliputi total fenol dan flavonoid serta kelompok terpenoid penyusun ekstrak etil asetat daun akway dan potensi farmakologis ekstrak etilasetat daun akway.

\section{METODOLOGI}

\section{Bahan dan Alat}

Bahan penelitian yang digunakan meliputi daun Drimys piperita, etilasetat dan metanol dari JT Baker, pereaksi folinchiocalteu, asam galat dan quersetin dari Merc Jerman, kalium hidroksida, asam klorida, kloroform, potasium asetat, alumunium klorida dan sodium karbonat dari Unilab dan aquades. Peralatan penelitian yang digunakan meliputi grinder miyako, ayakan, kertas saring whatman, rotary evaporator Eyela N1000, corong buchner, spektrofotometer UVmini1240 Shimadzu Jepang, GCMS-QP2010S Shimadzu Jepang dan peralatan gelas.

\section{Metode}

Penelitian ini adalah penelitian kuantitatif yang menggunakan metode deskriptif. Variabel yang diamati meliputi kandungan total fenol, flavonoid dan terpenoid ekstrak etilasetat daun akway.

\section{Preparasi Bahan Penelitian}

Bahan penelitian daun Drimys piperita yang digunakan dalam penelitian ini, dikumpulkan dari Distrik Anggi Pegunungan Arfak Papua Barat. Sampel daun dikumpulkan dari pohon dengan berdiameter batang sebesar 8-10 cm. Sampel daun dibersihkan dari kotoran dan debu yang menempel pada permukaannya menggunakan air mengalir. Daun yang sudah bersih ditiriskan lalu dikeringkan pada di ruang yang diperlengkapi dengan pendidngin ruangan bersuhu $18^{\circ} \mathrm{C}$ selama \pm 6 hari. Daun hasil pengeringan selanjutnya digiling menggunakan grinder kemudian diayak menggunakan ayakan 40 mesh. Bubuk hasil pengayakan dimasukkan ke dalam kemasan plastik dan ditutup rapat menggunakan sealer (Cepeda dkk., 2015).

\section{Ekstraksi Komponen Fitokimia}

Ekstraksi komponen fitokimia dalam bubuk daun menggunakan metode perendaman dalam pelarut etilasetat. Sebanyak 100 gram bubuk daun dimasukkan dalam labu erlenmeyer $1000 \mathrm{ml}$ selanjutnya ditambahkan pelarut etilaasetat $400 \mathrm{ml}$. Campuran selanjutnya dimasukkan ke dalam rotary 
evaporator bersuhu ruang dengan waktu inkubasi 3 hari. Setelah waktu ekstraksi selesai campuran disaring vakum menggunakan corong Buchner dan kertas saring whatman. Supernatan hasil penyaringan ditampung dan dikentalkan dalam dalam rotary evaporator suhu $40^{\circ} \mathrm{C}$ dan kecepatan putar 60 putaran permenit. Ekstrak hasil penguapan dimasukkan dalam botol dan dilakukan penguapan lanjutan di dalam refrigerator selama 7 hari sampai ekstrak memadat (Cepeda dkk., 2019).

\section{Pengujian Total fenol}

Penentuan kandungan total fenol ekstrak menggunakan metode Folin-Ciocateu (Modifikasi Do dkk., 2014). Sebanyak 1,6 ml ekstrak daun konsentrasi $50 \mu \mathrm{g} / \mathrm{ml}$ ditambahkan pereaksi Folin-Ciocalteu sebanyak 0,2 ml. Kemudian larutan diinkubasi dengan waktu 3 menit pada suhu ruang. Setelah waktu inkubasi selesai, larutan ditambahkan $0,2 \mathrm{ml} \mathrm{Na}_{2} \mathrm{CO}_{3} 10 \%$. Selanjutnya larutan diinkubasi pada suhu ruang dengan waktu 30 menit. Selanjutnya larutan ditentukan absorbansinya dengan spektrofotometer panjang gelombang $760 \mathrm{~nm}$. Kurva asam galat $20-80 \mu \mathrm{g} / \mathrm{ml}$ digunakan sebagai larutan standar. Kandungan total fenol ekstrak ditentukan berdasarkan kurva konsentrasi asam galat versus absorbansi menggunakan satuan $\mathrm{mg}$ ekivalen asam galat (mg EAG)/gram ekstrak.

\section{Pengujian Flavonoid}

Jumlah senyawa flavonoid di dalam ekstrak ditentukan menggunakan metode aluminum klorida (Modifikasi Do dkk., 2014). Sebanyak 0,1 gram ekstrak dilarutkan dalam pelarut metanol sampai volume $10 \mathrm{ml}$ (konsentrasi ekstrak 1\%). Ekstrak selanjutnya diencerkan dengan metanol sampai konsentrasi menjadi $0,1 \mathrm{mg} / \mathrm{ml}$. Sebanyak $2 \mathrm{ml}$ ekstrak 0,1 $\mathrm{mg} / \mathrm{ml}$ direaksikan dengan $0,1 \mathrm{ml} \mathrm{AlCl}_{3} 10 \%$ dan $0,1 \mathrm{ml} \mathrm{CH}_{3} \mathrm{CO}_{2} \mathrm{~K} 0,1 \mathrm{mM}$ pada suhu ruang pada waktu 30 menit. Selanjutnya larutan ditentukan absorbansinya dengan spektrofotometer panjang gelombang $415 \mathrm{~nm}$. Larutan quersetin dengan konsentrasi 2-10 $\mu \mathrm{g} / \mathrm{ml}$ digunakan sebagai larutan baku dalam pengujian. Kandungan flavonoid ditentukan berdasarkan kurva baku konsentrasi quersetin versus absorbansi dengan miligram ekivalen quersetin (mg EQ)/ gram ekstrak.

Fraksinasi Ekstrak
Sebanyak 1 gram ekstrak dilarutkan dalam etilesetat $30 \mathrm{ml}$ dan diaduk selama 1 menit pada suhu $40^{\circ} \mathrm{C}$ menggunakan inkubator bergoyang. Larutan selanjutnya disaring menggunakan kertas saring whatman no. 40 . Senyawa-senyawa yang bersifat asam dipisahkan dengan menambahkan filtrat $10 \mathrm{ml}$ larutan $\mathrm{KOH}$ 5\% sebanyak 3 kali. Penambahan larutan $\mathrm{KOH}$ ke dalam filtrat akan membentuk 2 fraksi, yaitu fraksi etilasetat dan fraksi $\mathrm{KOH}$. Selanjutnya Fraksi etilasetat dipisahkan dari fraksi $\mathrm{KOH}$ menggunakan labu pemisah. Selanjutnya senyawa-senyawa yang bersifat basa dalam fraksi etilasetat dipisahkan dengan menambahkan $10 \mathrm{ml}$ larutan $\mathrm{HCl}$ 5\% sebanyak 3 kali. Fraksi organik yang mengandung senyawa netral dicuci dengan menambahkan aquades sebanyak $30 \mathrm{ml}$. Kemudian fraksi etilasetat dikentalkan di dalam rotary evaporator dan disentrifus dengan kecepatan $6000 \mathrm{rpm}$ pada suhu $4^{\circ} \mathrm{C}$ untuk memisahkan partikel-partikel yang tersuspensi. Fraksi etilasetat diuapkan dan dikeringkan untuk mendapatkan fraksi terpenoid. Fraksi terpenoid selanjutnya dilarutkan dalam kloroform. (Cordeiro dkk., 1999).

\section{Identifikasi Senyawa terpenoid}

Identifkasi senyawa terpenoid dalam fraksi terpenoid dilakukan menggunakan peralatan Gas Chromatography Mass Spectroscopy, dengan kolom tipe HP-5MS, panjang kolom 30 meter dengan suhu $80^{\circ} \mathrm{C}$. Suhu injeksi larutan $290^{\circ} \mathrm{C}$, tekanan $16.5 \mathrm{kPa}$ menggunakan total aliran $80.0 \mathrm{ml} /$ menit serta kecepatan linier $26.1 \mathrm{~cm} /$ detik. Purge flow 3.0 $\mathrm{ml} /$ menit dengan split ratio 152.9 . ID $0.25 \mathrm{~mm}$ menggunakan Helium sebagai gas pembawa dengan pengionan EI 70Ev. Identifikasi senyawa terpenoid penyusun ekstrak dilakukan menggunakan Library: Wiley7.LIB (Cepeda dkk., 2011).

\section{Analisis data}

Data yang diperoleh dari hasil pengujian dianalisis secara tabulasi. Data hasil analisis ditampilkan dalam bentuk tabel dan gambar.

\section{HASIL DAN PEMBAHASAN}

\section{Kandungan Total fenol dan Flavonoid}

Pengujian kandungan fenol dan flavonoid dilakukan untuk mengetahui potensi farmakologis ekstrak etilasetat. Hasil perhitungan menunjukkan kandungan total 
fenol dan flavonoid ekstrak etilasetat daun akway masing-masing adalah 33,25 mg EAG/g dan 3,05 mg EQ/g ekstrak.

Kandungan senyawa fenolik ekstrak etilasetat daun akway, yaitu total fenol dan flavonoid relatif lebih rendah dibandingkan dengan ekstrak etanol daun Caesalpinia bonduc, yaitu sejumlah 146,64 mg EAG/g dan 31,05 mg EQ/g (Sembiring dkk, 2018) dan ekstrak metanol Caesia tora sebesar 287,73 mg EAG/g dan 37,86 mg EQ/g (Aryal dkk., 2019). Namun demikian kandungan total fenol ekstrak etilasetat daun akway lebih tinggi dibandingkan dengan ekstrak etilasetat daun Taraxacum officinale, yaitu sejumlah 10,2 mg EAG/g ekstrak dan ekstrak etilasetat daun Hemigraphis colorata sebesar $23 \mathrm{mg}$ EAG/g ekstrak (Kashyap dkk., 2013).

Senyawa fenol dan flavonoid yang diekstraksi dari berbagai sumber tumbuhan telah dibuktikan memiliki berbagai aktivitas farmakologis. Senyawa fenolik dilaporkan memiliki efek farmakologis, yaitu pencegahan cardiovascular disease, anti kanker dan aktivitas antidiabetes (Abbas dkk., 2017), antimikroba, antiviral, antioksidan, antiinflamasi dan antikarsinogenik (Kabera dkk., 2014).

\section{Kandungan Terpenoid}

Terpenoid adalah senyawa hidrokarbon tumbuhan yang tersusun dari unit isoprene $\left(\mathrm{C}_{5} \mathrm{H}_{8}\right)_{\mathrm{n}}$ juga turunannya dalam bentuk senyawa teroksigenasi, terhidrogenasi dan terdehidrogenasi (Yadaf dkk., 2014). Senyawa ini merupakan senyawa penyusun utama minyak volatil yang diisolasi dari berbagai tumbuhan aromatik.

Pengujian kandungan terpenoid dalam ekstrak etilasetat daun akway menggunakan GC-MS menampilkan bahwa fraksi terpenoid ekstrak etilasetat daun akway tersusun dari 82 jenis senyawa (Gambar 1). Identifikasi jenis senyawa penyusun fraksi terpenoid memperlihatkan bahwa $81,70 \%$ senyawa dapat teridentifikasi sedangkan $19,50 \%$ senyawa tidak teridentifikasi (Tabel 1).

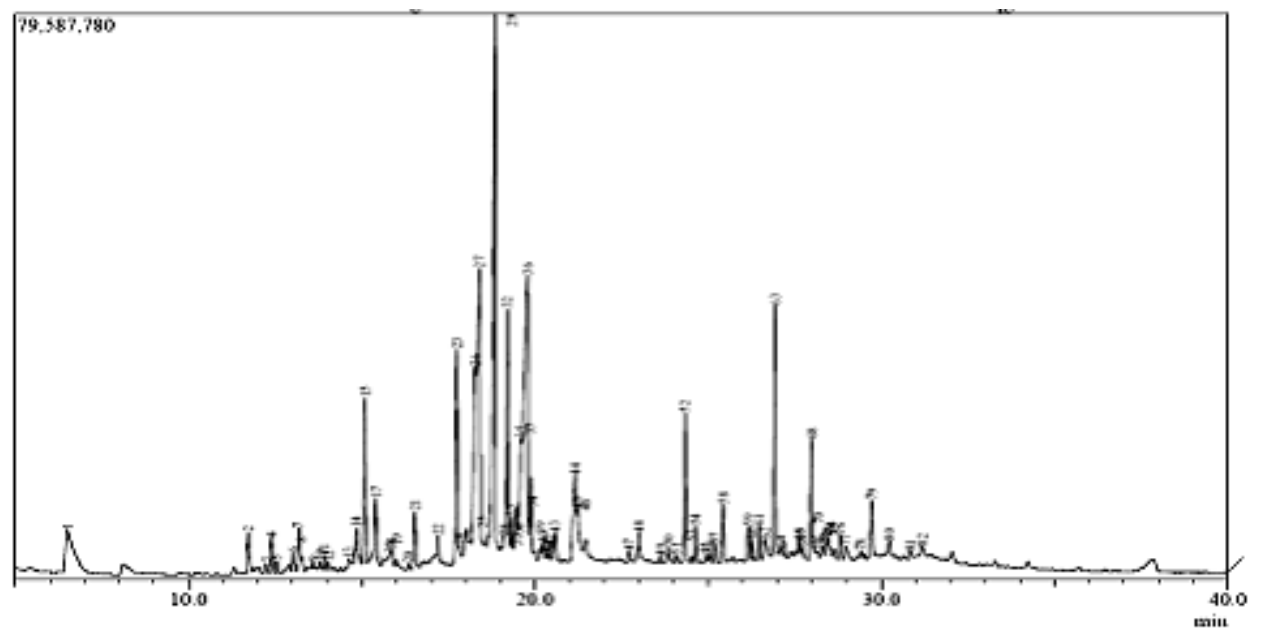

Gambar 1. Kromatogram senyawa terpenoid ekstrak

Tabel 1 juga memperlihatkan bahwa analisis GC-MS fraksi terpenoid tersusun oleh senyawa-senyawa caryophyllene $14.43 \%$, isopatchoulane $11,60 \%, \quad 7$-methanoasulen $6,21 \%$, humulene $4,76 \%$, Octadecane $4.24 \%$, t-phytol $3.46 \%$, linalool $3,20 \%$ dan 1,8 cyclotetradecadiyne $3,16 \%$. Senyawa-senyawa tersebut merupakan senyawa dengan komposisi terbesar di dalam fraksi terpenoid ekstrak etilasetat daun akway.
Tabel 1. Senyawa penyusun fraksi terpenoid

\begin{tabular}{|l|l|c|c|}
\hline No & \multicolumn{1}{|c|}{$\begin{array}{c}\text { Senyawa Fraksi } \\
\text { Terpenoid }\end{array}$} & $\begin{array}{c}\text { Waktu } \\
\text { Retensi } \\
(\text { menit }\end{array}$ & $\begin{array}{c}\text { Kons. } \\
(\%)\end{array}$ \\
\hline 1 & Linalool & 6.500 & 3,20 \\
\hline 2 & $\alpha$-Copaene & 11.25 & 0,9 \\
\hline 3 & $\alpha$-Gurjunene & 12.242 & 0,18 \\
\hline 4 & trans-Caryophyllene & 12.392 & 0,7 \\
\hline 5 & Germacrene D & 12.550 & 0,23 \\
\hline 6 & trans-Caryophyllene & 13.017 & 0,4 \\
\hline 7 & $\gamma$-Gurjunene & 13.183 & 0,77 \\
\hline 8 & $\alpha$-Copaene & 13.267 & 0,26 \\
\hline 9 & $\alpha$-Muurolene & 13.608 & 0,09 \\
\hline 10 & $\alpha$-Amorphene & 13.792 & 0,13 \\
\hline
\end{tabular}




\begin{tabular}{|c|c|c|c|}
\hline 11 & $\delta$-Cadinene & 13.925 & 0,21 \\
\hline 12 & $\begin{array}{l}\text { 7,11-dimethyl-3- } \\
\text { methylene-1,6,10- } \\
\text { Dodecatriene, }\end{array}$ & 14.042 & 0,13 \\
\hline 13 & $\begin{array}{l}\text { 3,7,11-trimethyl- } \\
\text { 1,6,10-Dodecatrien- } \\
\text { 3-ol }\end{array}$ & 14.625 & 0,43 \\
\hline 14 & Tidak teridentiikasi & 14.842 & 1,22 \\
\hline 15 & $\begin{array}{l}1,8- \\
\text { cyclotetradecadiyne }\end{array}$ & 15.100 & 3,16 \\
\hline 16 & $\begin{array}{l}\text { 2,6-dimethoxy-4-(2- } \\
\text { propenyl)-Phenol }\end{array}$ & 15.308 & 0,50 \\
\hline 17 & $\begin{array}{l}\text { Dehydro- } \\
\text { cycloisolongifolenox } \\
\text { id }\end{array}$ & 15.408 & 1,35 \\
\hline 18 & Isogeraniol & 15.850 & 0,21 \\
\hline 19 & Isocaryophyllene & 16.008 & 0,08 \\
\hline 20 & Palmitaldehyde & 16.350 & 0,08 \\
\hline 21 & Driminol & 16.542 & 1,00 \\
\hline 22 & 1-Octadecene & 17.208 & 0,26 \\
\hline 23 & trans-Phytol & 17.750 & 3,46 \\
\hline 24 & $\begin{array}{l}\text { 1-ethyl-2-heptyl- } \\
\text { cyclopropane }\end{array}$ & 17.808 & 0,30 \\
\hline 25 & 3-Octadecyne & 18.017 & 1,03 \\
\hline 26 & 7-Methanoazulene & 18.283 & 6,21 \\
\hline 27 & Tidak teridentifikasi & 18.400 & 8,52 \\
\hline 28 & $\begin{array}{l}\text { 3,7,11-trimethyl- } \\
\text { 2,6,10-Dodecatrien- } \\
\text { 1-ol }\end{array}$ & 18.650 & 1,05 \\
\hline 29 & Caryophyllene-oxide & 18.850 & 14,43 \\
\hline 30 & $\begin{array}{l}\text { 1-cyclopropyl-1- } \\
\text { pentanol }\end{array}$ & 19.017 & 0,53 \\
\hline 31 & Tidak teridentifikasi & 19.100 & 0,46 \\
\hline 32 & Humulene & 19.217 & 4,76 \\
\hline 33 & 1-Doce & 19.325 & 0,74 \\
\hline 34 & Hexadecanoic acid & 19.458 & 1,67 \\
\hline 35 & $\mathrm{C}_{14} \mathrm{H}_{22} \mathrm{O}$ & 19.600 & 2,63 \\
\hline 38 & Isopatchoulane & 19.792 & 11,60 \\
\hline 37 & Tidak teridentifikasi & 19.883 & 1,58 \\
\hline 38 & Tidak teridentifikasi & 20.008 & 0,25 \\
\hline 39 & Velleral & 20.158 & 0,25 \\
\hline 40 & $1 \mathrm{H}-\mathrm{In}$ & 20.233 & 0,34 \\
\hline 41 & $\begin{array}{l}1,11,13- \\
\text { Octadecatriene }\end{array}$ & 20.342 & 0,11 \\
\hline 42 & $\begin{array}{l}\text { Linolenic acid, } \\
\text { methyl ester }\end{array}$ & 20.408 & 0,19 \\
\hline 43 & Cis-caryophyllene & 20.575 & 0,70 \\
\hline 44 & $\begin{array}{l}\text { 6,9-Pentadecadien-1- } \\
\text { ol }\end{array}$ & 58 & 3,01 \\
\hline 45 & 1-Nonadecene & 21.242 & 1,05 \\
\hline 46 & $\begin{array}{l}\text { 1,7-diepoxy- } \\
\text { Tricyclotriacontan, }\end{array}$ & 21.458 & 0,58 \\
\hline 47 & $\begin{array}{l}4,8,12,16- \\
\text { Tetramethyl } \\
\text { heptadecan-4-olide }\end{array}$ & 22.717 & 0,14 \\
\hline 48 & 1-Docosene & 23.000 & 0,45 \\
\hline 49 & Farnesol-2 & 23.633 & 0,09 \\
\hline 50 & Hexadecane & 23.858 & 0,20 \\
\hline 51 & 2,3,5,8-tetramethyl- & 24.083 & 0,15 \\
\hline
\end{tabular}

\begin{tabular}{|l|l|l|r|}
\hline & 1,5,9-Decatriene, & & \\
\hline 52 & Di-n-octyl phthalate & 24.342 & 2,25 \\
\hline 53 & Neophytadiene & 24.525 & 0,10 \\
\hline 54 & 1-Tricosene & 24.633 & 0,52 \\
\hline 55 & Tetradecanal & 24.942 & 0,11 \\
\hline 56 & Tidak teridentifikasi & 25.067 & 0,14 \\
\hline 57 & Tidak teridentifikasi & 25.200 & 0,27 \\
\hline 58 & Octadecane & 25.433 & 0,97 \\
\hline 59 & Tetratetracontane & 26.167 & 0,65 \\
\hline 60 & Plexol & 26.267 & 0,32 \\
\hline 61 & Octadecanal & 26.467 & 0,50 \\
\hline & 4-acetyl-2,2,3,7- & 26.642 & 0,72 \\
62 & tetramethyltricyclo & & \\
\hline & unec-3-ene & & \\
\hline 63 & Octadecane & 26.933 & 4,24 \\
\hline 64 & Tidak teridentifikasi & 27.092 & 0,30 \\
\hline 65 & Tetradecanal & 27.192 & 0,23 \\
\hline 66 & n-Nonacosane & 27.617 & 0,16 \\
\hline 67 & Octanoic acid & 27.717 & 0,13 \\
\hline 68 & Hexadecanal & 27.912 & 2,06 \\
\hline 69 & Tidak teridentifikasi & 28.058 & 0,12 \\
\hline 70 & Tidak teridentifikasi & 28.183 & 0,26 \\
\hline 71 & Tidak teridentifikasi & 28.308 & 0,36 \\
\hline 72 & Octadecane & 28.408 & 0,23 \\
\hline 73 & Tidak teridentifikasi & 28.458 & 0,40 \\
\hline 74 & Tidak teridentifikasi & 28.533 & 0,20 \\
\hline 75 & 3,5-decadien-7-in & 28.633 & 0,24 \\
\hline 76 & Hexadecanal & 28.817 & 0,43 \\
\hline 77 & Tidak teridentifikasi & 28.975 & 0,34 \\
\hline 78 & 1-Docosanol-acetate & 29.400 & 0,08 \\
\hline 79 & Hexadecanal & 29.725 & 1,04 \\
\hline 80 & Tidak teridentifikasi & 30.233 & 0,24 \\
\hline 81 & Tidak teridentifikasi & 30.833 & 0,15 \\
\hline 82 & Cedranone & 31.183 & 0,20 \\
\hline & Kelompok senyawa & \\
\hline
\end{tabular}

Kelompok senyawa terpenoid terdiri dari senyawa monoterpen $\left(\mathrm{C}_{10} \mathrm{H}_{16}\right)$, sesquiterpen $\left(\mathrm{C}_{15} \mathrm{H}_{24}\right)$, diterpen $\left(\mathrm{C}_{20} \mathrm{H}_{32}\right)$, sesterpen $\left(\mathrm{C}_{25} \mathrm{H}_{40}\right)$, Troterpen $\left(\mathrm{C}_{30} \mathrm{H}_{48}\right)$, tetraterpenoid (C40H64), dan politerpen (Yadav dkk., 2014). Senyawa penyusun terbesar fraksi terpenoid ekstrak etilasetat daun akway terdiri atas : (a) 4 senyawa sesquiterpen, yaitu caryophyllene, isopatchoulane, 7methanoazulen dan humulene dengan formula molekul $\mathrm{C}_{15} \mathrm{H}_{24}$, (b) 1 senyawa monoterpen, yaitu linalool $\left(\mathrm{C}_{10} \mathrm{H}_{16}\right)$, (c) 1 senyawa diterpen, yaitu phytol $\left(\mathrm{C}_{20} \mathrm{H}_{32}\right)$ dan (d) 1 senyawa hidrokarbon alifatik, yaitu octadecane dan (e) 1 senyawa hidrokarbon siklik, yaitu 1,8cyclotetradecadiyne (Gambar 2). Sesquiterpen caryophyllene merupakan senyawa dengan konsentrasi terbesar dalam fraksi terpenoid ekstrak daun akway. Di alam senyawa ini ditemukan dalam beberapa tipe, yaitu transcaryophyllene, $\alpha$-caryophyllene ( $\alpha$-humulene), isocaryophyllene dan caryophylene oxide (Francomano dkk., 2019). 


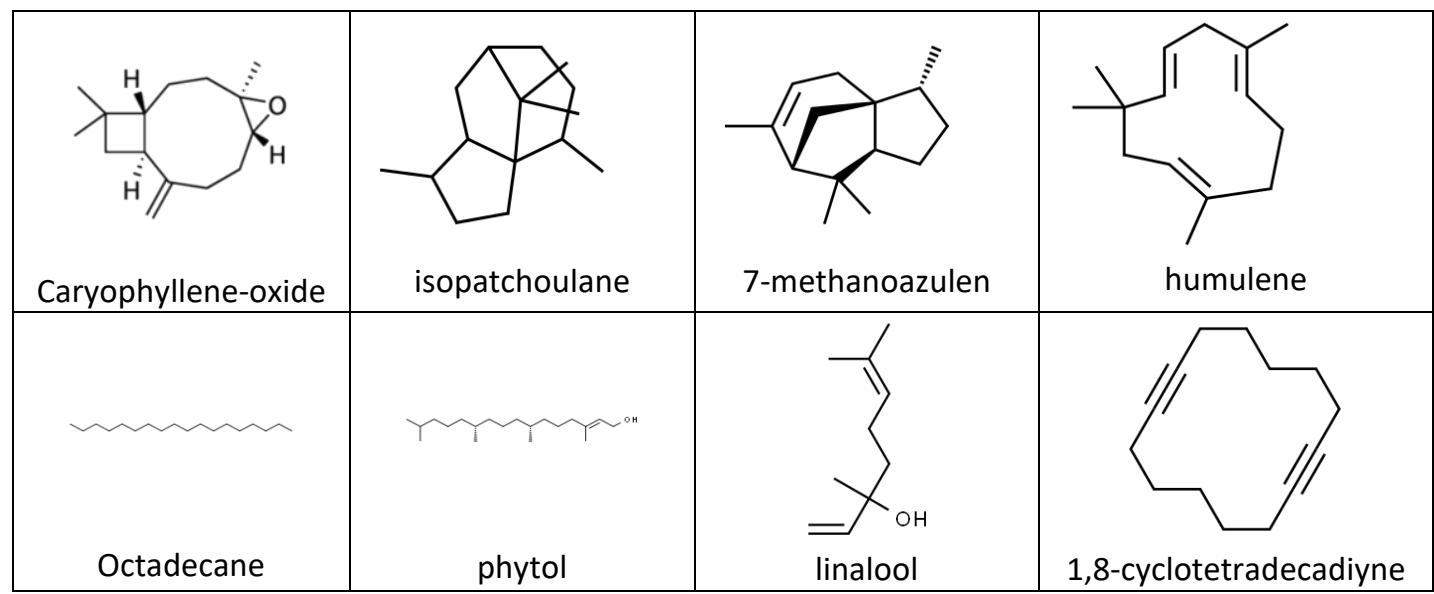

Gambar 2. Struktur molekul senyawa penyusun terbesar fraksi terpenoid

Sesquiterpene caryophyllen oxide merupakan bentuk teroksidasi dari $\beta$ caryophyllene. Senyawa ini dapat ditemukan pada rempah kemangi (Ocimum spp.), oregano (Origanum vulgare L.), kayu manis (Cinnamomum spp.), rosemary (Rosmarinus officinalis), lavender (Lavandula angustifolia), cengkeh (Syzygium aromaticum), cannabis (Cannabis sativa L.), and merica hitam (Piper nigrum L.) (Fidyt dkk., 2016). Senyawa ini dilaporkan memiliki aktivitas anticancer, analgesik, antiinflamasi, antidepresif, antitumor, antioksidan dan neuroprotektif (Fidyt dkk., 2016; Francomano dkk., 2019).

\section{KESIMPULAN}

Ekstrak etilasetat daun akway mengandung total fenol dan flavonoid masingmasing sebesar 33,25 mg EAG/g dan 3,05 mg $\mathrm{EQ} / \mathrm{g}$ ekstrak. Senyawa penyusun terbesar dalam fraksi terpenoid ekstrak etilasetat daun akway adalah caryophyllene $14.43 \%$, isopatchoulane $11,60 \%, \quad 7$-methanoasulen $6,21 \%$, humulene $4,76 \%$, Octadecane $4.24 \%$, t-phytol $3.46 \%$, linalool $3,20 \%$ dan 1,8 cyclotetradecadiyne $3,16 \%$. Ekstrak etilasetat daun akway berpotensi sebagai sumber senyawa pencegah penyakit jantung, antikanker, antitumor, aktivitas antidiabetes, antimikroba, analgesik, antiviral, neuroprotectif antioksidan, antiinflamasi antidepresif dan anticarsinogenik.

\section{DAFTAR PUSTAKA}

Abbas, M., Saeed, F., Anjum, F. M., Afzaal, M., Tufail, T., Bashir, M. S., Ishtiaq, A.,
Hussain, S. \& Suleria, H,. A. R. (2017). Natural polyphenols: An overview. International Journal of Food Properties, 20(8) : 1689-1699.

Aryal, S., Baniya, M. K., Danekhu, K., Kunwar, P., Gurung, R., \& Koirala, N. (2019). Total Phenolic Content, Flavonoid Content and Antioxidant Potential of Wild Vegetables from Western Nepal. Plants, 8(96) : 1-12.

Cepeda, G.N., Santoso, B.B., Lisangan, M.M. \& Silamba, I. (2011a). Komposisi kimia minyak atsiri daun akway. Makara Sains 15(1): 63-66.

Cepeda, G.N., Santoso, B.B., Lisangan, M.M. \& Silamba, I. (2011b). Komposisi kimia minyak atsiri kulit kayu akway (Drimys piperita Hook f.). Bionatura 13(2) : 118124.

Cepeda, G. N., Lisangan, M. M., \& Roreng, M. K. (2018). Aktivitas penangkalan radikal bebas dan kemampuan reduksi ekstrak kulit kayu akway (Drimys piperita Hook. f.). Jurnal Aplikasi Teknologi Pangan 7(4): 168-173.

Cepeda, G.N., Lisangan, M.M. \& Silamba, I. (2015). Aktivitas antibakteri ekstrak kulit kayu akway (Drimys piperita Hook f.) terhadap bakteri patogen. Agritech, 35(2): 170-177. doi:10.22146/agritech.9403.

Cepeda, G.N., Lisangan, M.M. \& Silamba, I. (2019). Aktivitas antibakteri minyak atsiri kulit kayu akway (Drimys piperita Hook. f.) pada beberapa tingkat konsentrasi, keasaman $(\mathrm{pH})$ dan kandungan garam. Jurnal Aplikasi Teknologi Pangan, 8 (4): 149-154. 
Cepeda, G. N., Lisangan, M. M., Silamba, I., Nilawati, N., Syartika, E. 2020. Sifat antibakteri ekstrak etanol daun akway (Drimys piperita) terhadap pertumbuhan B. cereus dan S. aureus secara in vitro. Jurnal Sains dan Teknologi Pangan, 5(3): 2851-2862.

Cordeiro P. J. M., Y. Vilegas, F. M. Lancas. 1999. HRGC-MS analysis of terpenoids from Maytenus ilicifolia and Maytenus aquifolium ("Esinheira Santa"). Journal of the Brazilian Chemical Society. 10(6): 523-526

Do, Q.D., Angkawijaya, A.E., Tran-Nguyen, P.L., Huynh, L.H., Soetaredjo, F. E., Ismadji, S., Ju, YH. 2014. Effect of extraction solvent on total phenol content, total flavonoid content, and antioxidant activity of Limnophila aromatic. Journal of Food and Drug Analysis, 22(3): 296 - 302.

Fidyt1, K., Fiedorowicz, A., Strzadała, L., \& Szumny, A. (2016). $\beta$-caryophyllene and $\beta$-caryophyllene oxide-natural compounds of anticancer and analgesic properties. Cancer Medicine, 5(10):3007-3017.

Francomano, F., Caruso, A., Barbarossa, A., Fazio, A., La Torre, C., Ceramella, J., Mallamaci, R., Saturnino, C., Iacopetta, D., \& Sinicropi, M. S. (2019). $\beta$ Caryophyllene: A Sesquiterpene with Countless Biological Properties. Appllied Sciences, 9(5420): 1-19.
Kabera, J. N., Semana, E., Mussa, A. R., \& He, X. (2014). Plant Secondary Metabolites: Biosynthesis, Classification, Function and Pharmacological Properties. Journal of Pharmacy and Pharmacology, 2(7) : 377-392.

Kashyap, A. K., Reddy, N. P., Chaitanya, R. K., \& Karnati, R. (2013). Ethyl acetate extract of Hemigraphis colorata leaves shows anti-inflammatory and wound healing properties and inhibits 5lipoxygenase and cyclooxygenase- 1 and 2 enzymes. Journal of Medicinal Plants Research, 7(37) : 2783-2791.

Pagare, S., Bhatia, M., Tripathi, N., Pagare, S., Bansal., Y.K. 2015. Secondary Metabolites of Plants and their Role: Overview. Current Trends in Biotechnology and Pharmacy, 9(3): 293-304.

Sembiring, E. N., Elya, B., \& Sauriasari, R. (2018). Phytochemical Screening, Total Flavonoid and Total Phenolic Content and Antioxidant Activity of Different Parts of Caesalpinia bonduc (L.) Roxb. Pharmacognosy Journal, 10 (1) : 123127.

Yadav, N., Yadav, R., \& Goyal, A. (2014). Chemistry of Terpenoids. International Journal of Pharmaceutical Sciences Review and Research, 27(2): 272-278. 